\title{
Adsorption of BSA (Bovine Serum Albuminum) and lysozyme on poly(vinyl acetate) particles
}

\author{
Dirceu Pereira dos Santos ${ }^{1}$, Tito Lívio Moitinho Alves ${ }^{1}$ and José Carlos Pinto ${ }^{1 *}$ \\ 'Programa de Engenharia Química, Instituto Alberto Luiz Coimbra de Pós-Graduação e Pesquisa em \\ Engenharia - COPPE, Universidade Federal do Rio Janeiro - UFRJ, Rio de Janeiro, RJ, Brazil \\ *pinto@peq.coppe.ufrj.br
}

\begin{abstract}
Poly(vinyl acetate) (PVAc) particles find many uses in the biomedical field, including the use as particle embolizers. Particularly, embolizing particles can combine physical and chemical effects when they are doped with pharmaceuticals. For this reason, the adsorption of bovine serum albuminum (BSA) and lysozyme (used as model biomolecules) on PVAc particles produced through suspension polymerization is studied in the present manuscript in a broad range of $\mathrm{pH}$ values. It is shown that significant amounts of BSA and lysozyme can be adsorbed onto PVAc particles in the vicinities of the isoelectric point of the biomolecules $(0.65 \mathrm{mg}$ of BSA and $1.0 \mathrm{mg}$ of lysozyme per $\mathrm{g}$ of PVAc), allowing for production of chemoembolizers through adsorption. Particularly, it is shown that lysozyme still presents residual activity after the adsorption process, which can constitute very important characteristic for real biomedical applications.
\end{abstract}

Keywords: poly(vinyl acetate), lysozyme, Bovine Serum Albuminum (BSA), suspension polymerization, adsorption.

\section{Introduction}

Different methods have been used to load drugs (or biological active substances) into polymer matrices, including co-precipitation, in-situ incorporation and adsorption ${ }^{[1-15]}$. In co-precipitation processes, the doped polymer beads are prepared through precipitation from a solution that contains both the drug and the polymer resin. When the drug incorporation is performed in situ, the drug is solubilized in the reaction medium before the synthesis of the polymer powder, which is formed in the presence of the drug. When adsorption processes are used, the drug is added to a medium that contains the suspended polymer material after production of the polymer matrix. When the adsorption technique is carried out, the drug is expected to be predominantly on the surface of the polymer bead.

Vascular embolization is a medical procedure that consists in occluding a blood vessel intentionally by injecting a fine material (the embolic agent or embolizer) into the blood vesse $^{[16-18]}$. Embolization techniques have been used to treat several clinical problems, including treatment of malignant tumors and arteriovenous malformation ${ }^{[16-20]}$. Transarterial chemoembolization is a medical technique that combines the application of a drug with an embolic agent, leading to local chemical and physical actions during treatment ${ }^{[21-24]}$. This encourages the development of techniques intended to load biological molecules onto embolizing polymer microparticles.

Several commercial products are available for embolization and many of them are based on poly(vinyl alcohol) (PVA) and poly(vinyl acetate) (PVAc) microparticles ${ }^{[13-15,25-27]}$. Although PVAc is well known for its excellent adhesive properties ${ }^{[28]}$, PVAc is also used in a broad range of applications, including medical applications, due to its biocompatibility ${ }^{[29-31]}$. For this reason, Pinto and coworkers ${ }^{[13-15,25,30,32-34]}$ developed a sequential two-stage process to allow for production of spherical PVAc/PVA particles with core-shell morphology to be used as embolizers. Based on this process, additional studies were carried out to modify the final properties of the particles ${ }^{[32-34]}$. In order to load PVAc microparticles with bioactive compounds for posterior use as chemoembolizers, it is important to analyze how PVAc microparticles interact with model biological molecules.

Bovine Serum Albuminum (BSA) is a model biological molecule that finds widespread use in the biotechnological and biomedical fields. Particularly, BSA has been used as a drug delivery agent, due to its capacity to bond covalently to different drug ${ }^{[35-37]}$. BSA is a protein composed of 583 aminoacid residues, has molar mass of $66430 \mathrm{~g} / \mathrm{gmol}$, is very soluble in water (it can be precipitated in high concentrations of a neutral salt, such as ammonium sulphate), has isoelectric point in the $\mathrm{pH}$ range of 4.60-5.70, and presents spheroidal shape, characteristic sizes of $4 \mathrm{~nm} \times 4 \mathrm{~nm} \times 14 \mathrm{~nm}$ and Stoke radius of $3.48 \mathrm{~nm}^{[38-40]}$.

Lysozyme is another model biological molecule that finds many uses in the biotechnological and biomedical fields. Particularly, lysozyme has been employed as an antibiotic in films intended for food packaging ${ }^{[41-42]}$. For this reason, immobilization of lysozyme has been performed in different polymer materials, including cellulose acetate, nylon, chitosan and alginates ${ }^{[43]}$. Lysozyme is an enzyme produced by bacteria, fungi, plants and animals, presenting 129 aminoacid residues, molar mass of $14400 \mathrm{~g} / \mathrm{gmol}$ and isoelectric point in the $\mathrm{pH} 11.00^{[44-46]}$.

It is important to emphasize that PVAc microparticles have not been used as supports for adsorption of enzymes in previous studies. However, the use of PVAc-based particle embolizers loaded with enzymes can be very advantageous in real medical applications, as the physical benefits provided by the occlusion of blood vessels can be combined with 
the chemical benefits provided by the enzyme activity in the local embolized tissue. This certainly encourages the analysis of the enzymatic adsorption process over PVAc microparticles.

Based on the previous remarks, the main objective of the present manuscript is analyzing for the first time how PVAc microparticles interact with BSA and lysozyme during adsorption experiments performed in aqueous suspensions. BSA and lysozyme are used here as model biological molecules in order to evaluate the efficiency of the adsorption process for the eventual preparation of chemoembolyzers through adsorption. It is shown in both cases that immobilization was more efficient in the vicinities of the isoelectric point of the protein, leading to loads of $0.65 \mathrm{mg}$ of BSA and $1.0 \mathrm{mg}$ of lysozyme per $\mathrm{g}$ of PVAc, which are comparable to the amounts required for some of the standard chemoterapic procedures. Particularly, it is shown that lysozyme still presents residual activity after the adsorption process, which can constitute very important characteristic for real biomedical applications.

\section{Materials and Methods}

\subsection{Reagents}

All chemical reagents used for production of PVAc microparticles were purchased from Vetec (Rio de Janeiro, Brazil) in analytical grade, with minimum purity of $99.5 \mathrm{wt} \%$, and used as received. BSA and lysozyme were purchased from Sigma-Aldrich (Rio de Janeiro, Brazil) as pure liofilized proteins and used as received. Protein concentrations and enzymatic activities were characterized as described below prior to adsorption experiments. Water was distilled and demineralized prior to use.

\subsection{Suspension polymerization reactions}

PVAc microparticles were prepared through suspension polymerization, as described elesewhere ${ }^{[13-15,25,30,32-34]}$. Reaction runs were performed in an 1-liter jacketed glass reactor, equipped with a stainless steel lid and a standard six-blade stainless steel turbine impeller. Initially, a suspending agent solution containing $0.2 \mathrm{~g}$ of PVA (weight average molecular weight of $78 \times 10^{3} \mathrm{~g} / \mathrm{gmol}$ and degree of hydrolysis of $88 \%$, as reported by the producer) in $420 \mathrm{~g}$ of distilled water was prepared at room temperature. Afterwards, the monomer solution was prepared by dissolving $4 \mathrm{~g}$ of the free-radical initiator benzoyl peroxide (BPO, containing $25 \%$ of humidity) in $200 \mathrm{~g}$ of vinyl acetate (monomer, with minimum purity of $99.9 \%$ ). The PVA solution was added to the reactor first and heated to $85^{\circ} \mathrm{C}$, when the monomer solution was fed into the reactor. The reacting mixture was kept under continuous agitation of $1000 \mathrm{rpm}$ for 4 hours. Finally, polymer particles were separated through vacuum filtration, washed with abundant cold distilled water and dried until constant weight in a vacuum oven at $40^{\circ} \mathrm{C}$.

\subsection{Polymer characterization}

The molecular weight distribution and molecular weight averages of the produced PVAc microparticles were determined through standard gel permeation chromatography (GPC) at room temperature and using tetrahydrofuran
(THF, chromatographic grade) as the mobile phase. Analyses were performed in a Waters 600E equipment (Waters, US) equipped with a Waters 2414 refractive index detector and Ultrastyragel columns with porosity of $10^{3}, 10^{4}$ and $10^{5} \AA$. Calibration was carried out with polystyrene standards with weight-average molecular weights ranging from $5 \times 10^{3}$ to $3.0 \times 10^{6} \mathrm{~g} / \mathrm{mol}$.

The characteristic transition temperatures of the produced PVAc microparticles were determined through standard differential scanning calorimetry (DSC) analyses. Experiments were performed with help of a DSC7 equipment (Perkin-Elmer, US), using empty aluminum pans as references and heating rates of $10^{\circ} \mathrm{C} / \mathrm{min}$ in the range of 0 to $200^{\circ} \mathrm{C}$. In all cases, data were collected during the second heating scan in order to erase the previous thermal history of the polymer samples.

The morphology of obtained PVAc microparticles was characterized through optical microscopy, using a SMZ 800 microscope (Nikon, Japan) equipped with a Coolpix 995 digital camera (Nikon, Japan).

Zeta potential analyses of the produced PVAc microparticles were performed through streaming potential measurements in a SurPASS Electrokinetic Analyzer (Anton-Parr, US). Measurements were conducted in a background electrolyte solution containing $10 \mathrm{mM}$ of $\mathrm{KCl}$ over the $\mathrm{pH}$ range of 2 to 12 range at $25^{\circ} \mathrm{C}$, as recommended in the literature ${ }^{[47]}$. The solution $\mathrm{pH}$ was adjusted by addition of $\mathrm{NaOH}$ or $\mathrm{HCl}$.

Hydrophobicity analyses of the obtained PVAc product were performed with polymer films produced through slow solvent evaporation in vacuum ovens kept at room temperature until constant weight, from initial polymer solutions containing $4 \mathrm{wt} \%$ of polymer and $96 \mathrm{wt} \%$ of THF. The film was placed in a SCA 20 goniometer (Dataphysics, US) and contact angles were measured in triplicates at five different regions of the film.

Particle size distributions (PSD) of the final PVAc microparticles were determined through standard dynamic light scattering analyses performed in a Hydro 2000S equipment (Malvern Instruments, US). Measurements were performed in dilute aqueous dispersions at room temperature.

\subsection{Protein immobilization (adsorption)}

Protein immobilization was performed through physical adsorption, keeping $10 \mathrm{ml}$ of aqueous protein solution (in sodium phosphate buffer of $0.05 \mathrm{M}$ ) with known protein concentration in contact with 1 or $2 \mathrm{~g}$ of PVAc microparticles for different periods of time under agitation of 250rpm at $30{ }^{\circ} \mathrm{C}$ in an orbital shaker (New Brunswick, US). The masses of polymer powder were defined to allow for effective mixing of the solid-liquid suspension and provide sufficient area for protein adsorption, as discussed in the next section. Adsorption experiments were carried out at $\mathrm{pH}$ values of 3.0, 5.0, 6.8, 8.6 and 10.8. The solution $\mathrm{pH}$ was adjusted by addition of $\mathrm{NaOH}$ or $\mathrm{HCl}$.

\subsection{Protein concentration}

Standard Bradford analyses were performed to determine protein concentrations in the BSA and lysozyme aqueous solutions ${ }^{[48]}$. Initially, $1 \mathrm{ml}$ of the Bradford solution was 
added to an Eppendorf, followed by addition of $0.2 \mathrm{ml}$ of the sample solution or of the standard solution (used for calibration) at room temperature. After 10 minutes, light absorbance was measured with help of a UV-Mini spectrometer (Shimadzu, Japan) at the wavelength of 600nm. Calibration was performed with pure liofilized BSA samples.

\subsection{Enzymatic lisozyme activity}

Enzymatic lysozyme activity was determined as described by the Sigma-Aldrich protocol. According to this procedure, $2.5 \mathrm{ml}$ of an aqueous solution $(66 \mathrm{mM}$ potassium phosphate buffer at $\mathrm{pH} 6.22$ ) containing $0.01 \mathrm{wt} \%$ of liofilized Micrococcus powder (Sigma-Aldrich, Rio de Janeiro) were placed in a cuvette with optical path of $1 \mathrm{~cm}$. Afterwards, $0.1 \mathrm{ml}$ of the sample lysozyme solution was added to the cuvette. Light absorbance readings (at least five) were then performed within the first minute of reaction, using absorbance of the original potassium phosphate buffer as base line. The enzymatic activity is proportional to the angular coefficient of absorbance readings, as function of the reaction time. Light absorbance was measured with help of a UV-Mini spectrometer (Shimadzu, Japan) at the wavelength of $450 \mathrm{~nm}$. Calibration was performed with pure liofilized lysozyme samples. All experiments were performed at constant temperature of $25^{\circ} \mathrm{C}$.

In order to evaluate the effect of $\mathrm{pH}$ on the enzymatic lisozyme activity, aqueous lysozyme solutions $(0.05 \mathrm{M}$ sodium phosphate buffer and $0.1 \mathrm{~g} / 1$ of enzyme) were prepared at $\mathrm{pH}$ values of $3.0,5.0,6.8,8.6$ and 10.8 and submitted to enzymatic activity tests. Similarly, in order to evaluate the effect of vinyl acetate on the enzymatic lisozyme activity, aqueous lysozyme solutions $(0.05 \mathrm{M}$ sodium phosphate buffer, $\mathrm{pH}$ of 6.8 and $0.1 \mathrm{~g} / \mathrm{l}$ of enzyme) were prepared, put in contact with different amounts of vinyl acetate $(0,1,5,10,25,50$ and $95 \mathrm{wt} \%$ of VAc) and submitted to enzymatic activity tests. In all cases, the solution $\mathrm{pH}$ was adjusted by addition of $\mathrm{NaOH}$ or $\mathrm{HCl}$.

\section{Results and Discussions}

\subsection{Polymer characterization}

Obtained PVAc microparticles had the usual spherical shape of suspension polymer powders, as seen in Figure 1. Particles presented smooth surfaces and nonporous structure, as also characterized in previous works ${ }^{[13-15,25,30,32-34]}$. Besides, number-average molecular weight, weight-average molecular weight and polydispersity of the produced resins were equal to $33 \times 10^{3} \mathrm{~g} / \mathrm{gmol}, 84 \times 10^{3} \mathrm{~g} / \mathrm{gmol}$ and 2.55 , respectively, as in typical PVAc materials produced in similar conditions ${ }^{[13-15,25,30,32-34]}$. The glass transition temperature $(\mathrm{Tg})$ was equal to $42{ }^{\circ} \mathrm{C}$, which is also characteristic of PVAc powders $^{[13-15,25,30,32-34]}$. Monomer conversion was very high and close to $100 \%$, so that residual monomer could not be detected by standard gas chromatograph and nuclear magnetic resonance analyses, after washing and vacuum drying of the polymer particles.

Figure 2 shows the particle size distribution of the obtained PVAc microparticles, which present volume-average diameter of $200 \mu \mathrm{m}$ and standard deviation of $90 \mu \mathrm{m}$, with $95 \%$ of the mass contained in the diameter range of $50-550 \mu \mathrm{m}$. As broad

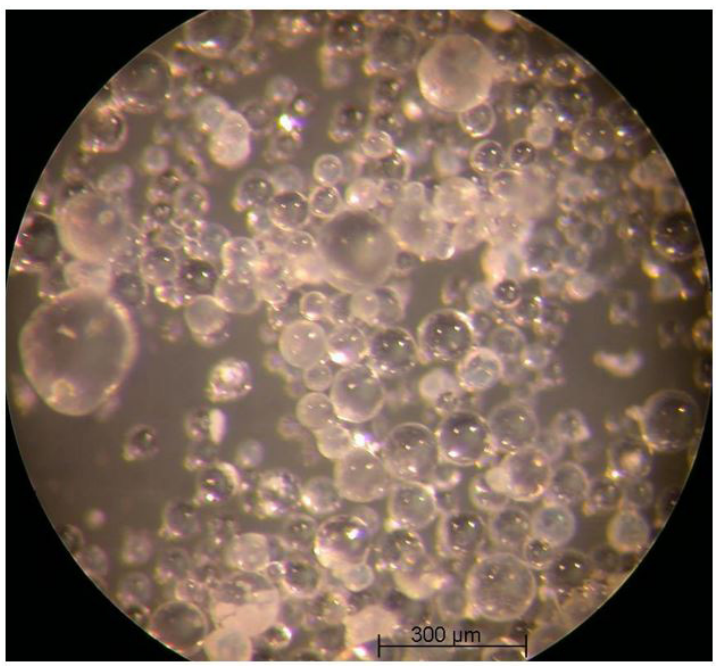

Figure 1. Optical micrograph of obtained PVAc microparticles.

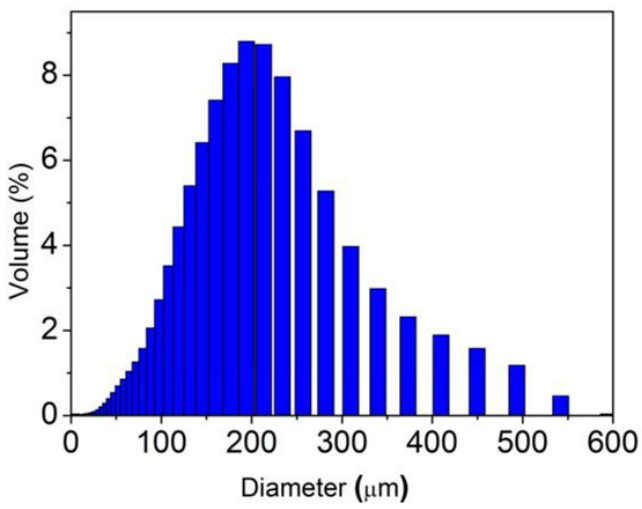

Figure 2. Particle size distribution of obtained PVAc microparticles.

particle size distributions is a characteristic of polymer powders produced through suspension polymerization, particle sieving and classification may be eventually necessary for some applications, including embolization. However, particle classification was not conducted here for execution of adsorption studies because polymer particles were nonporous, spherical and compact, with characteristic dimensions that were many orders of magnitude higher than the dimensions of the molecules involved in the experimental study, rendering the flat surface assumption valid for analysis of the obtained data.

According to the distribution shown in Figure 2 and assuming that the obtained microparticles were nonporous and spherical, it was possible to calculate the specific area of the microparticles as equal to $0.026 \mathrm{~m}^{2} / \mathrm{g}$. Similar results have been reported previously with help of standard BET analyses ${ }^{[25,33]}$. As one might already expect for suspension powders, the specific area of the microparticles can be regarded as very low (below the detection limits of most experimental techniques used to characterize specific areas of solid powders), so that the analyzed PVAc microparticles would barely be recommended as supports for preparation of enzymatic catalysts. Despite that, as these microparticles 
can be used as embolizers, the supporting of small amounts of bioactive molecules on the external microparticle surface can exert beneficial effects on the performance of the final product.

The contact angle of the obtained PVAc product was equal to $79^{\circ}$, indicating that particles presented a hydrophilic character, probably enhanced by the PVA suspending agent, which is expected to form a very thin film around the particle surfaces. The zeta potential of the obtained PVAc microparticles is shown in Figure 3. It can be observed that the isoelectric point of the obtained PVAc microparticles is placed at the vicinities of the $\mathrm{pH}$ value of 3.0 , indicating that the surfaces of the microparticles are charged negatively (and weakly) in almost the entire range of analyzed $\mathrm{pH}$ values. Again, the weak accumulation of negative charges on the PVAc microparticle surfaces can be due to the presence of the PVA suspending agent, but also due to the spontaneous hydrolysis of the ester groups of PVAc molecules, which is enhanced in basic aqueous media $^{[25]}$. It is important to emphasize that the accumulation of negative charges on the surfaces of the microparticles can allow for efficient immobilization of proteins when they are charged positively, if it is assumed that charge balance controls the adsorption process.

\subsection{Enzymatic lisozyme activity}

Figure 4 shows how the enzymatic lisozyme activity changes with the $\mathrm{pH}$ of the prepared aqueous solution. According to Figure 4, the maximum enzymatic activity of lysozyme is observed at the $\mathrm{pH}$ of 6.80 , which is the average $\mathrm{pH}$ of body liquids and is very close to the neutral $\mathrm{pH}$. In Figure 4 one can also observe that the enzymatic lisozyme activity is not very sensitive to $\mathrm{pH}$ variations at the acidic region, but decreases pronouncedly in the alkaline region. (Complete denaturation of the enzyme was observed at the $\mathrm{pH}$ of 10.80 after 24 hours.) Similar results were reported in other studies and at different temperatures ${ }^{[49-52]}$.

As monomer conversion never reaches $100 \%$, small amounts of vinyl acetate can possibly be released during the immobilization process, despite the efforts to purify the produced PVAc microparticles. For this reason, the enzymatic lisozyme activity was characterized in presence of vinyl acetate. As lysozyme is not soluble in vinyl acetate and the solubility of vinyl acetate in water is very small (around $2.5 \mathrm{wt} \%$ at $30^{\circ} \mathrm{C}$ ), some experiments were performed in presence of two phases: an aqueous phase and an organic phase. Figure 5 shows how the enzymatic lisozyme activity of aliquots of the aqueous phase changes with the amount of vinyl acetate added to the lisozyme solution. It can be observed that the presence of vinyl acetate can lead to significant increase (30\%) of the observed lisozyme activity. As the vinyl acetate content increases (and saturation of the aqueous phase takes place), a constant activity value is attained (although the experimental errors also increase possibly because of the unavoidable presence of very small organic droplets in the aqueous aliquots). As discussed in the literature ${ }^{[53]}$, the presence of small amounts of organic solvents in the enzyme solution can stabilize the protein structure (conformation) and allows for enhanced enzymatic

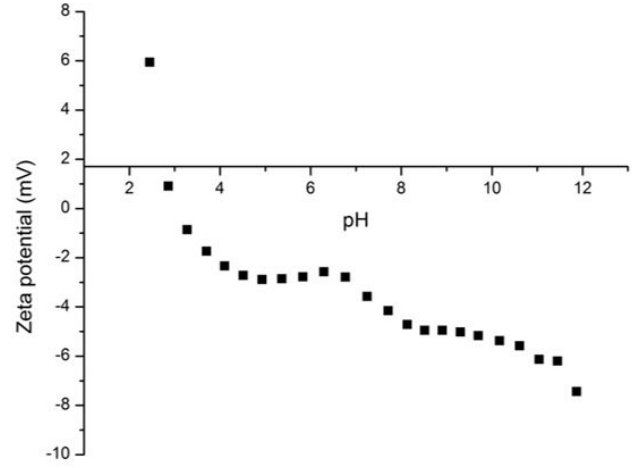

Figure 3. Zeta potential of obtained PVAc microparticles at different $\mathrm{pH}$ values.

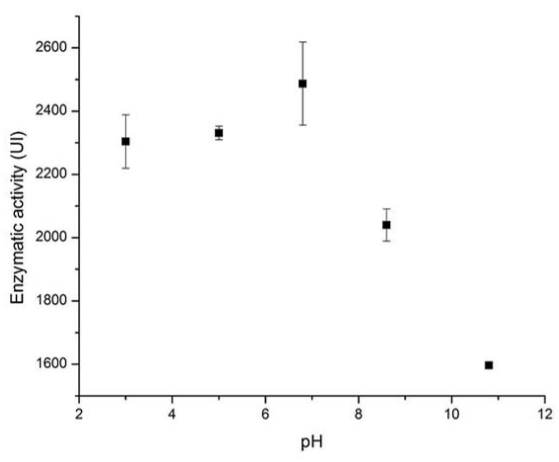

Figure 4. Enzymatic activity of lisozyme at different $\mathrm{pH}$ values.

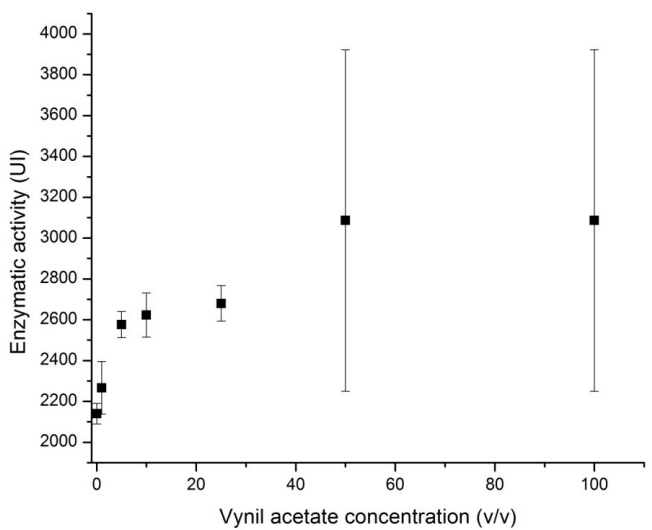

Figure 5. Enzymatic activity of lisozyme in presence of vinyl acetate.

activity, as observed here when small amounts of vinyl acetate are added to the aqueous lisozyme solution.

\subsection{Adsorption experiments}

A summary of the experimental design used to perform the adsorption experiments for both BSA and lisozyme is presented in Table 1. All experiments were performed at least three times in order to guarantee the statistical significance of the obtained results. 
Figure 6 shows how the concentrations of BSA in the aqueous phase changed when the protein solution was kept in contact with the PVAc microparticles for 24 hours at $30^{\circ} \mathrm{C}$. As one can observe, significant changes of BSA concentrations could only be observed when the $\mathrm{pH}$ was equal to 5.0, which is close to the isoelectric point of BSA. It is important to note that similar results were obtained when different amounts of PVAc ( 1 or $2 g$ ) were used, indicating that the obtained results were not controlled only by the small specific areas of the produced PVAc powder. When similar experiments were performed at $10^{\circ} \mathrm{C}$, no significant change of the BSA concentrations could be observed in the aqueous phase, indicating that temperature exerts a pronounced effect on the efficiency of BSA adsorption onto the PVAc microparticles. When temperature was equal to $35^{\circ} \mathrm{C}$, results were similar to the ones reported for $30^{\circ} \mathrm{C}$. Additional increase of temperature was not possible because coagulation of PVAc particles takes place, due to the low $\mathrm{Tg}$ value of the polymer resin.

Although lower temperatures usually tend to favor physical adsorption processes ${ }^{[54]}$, the immobilization of BSA onto PVAc microparticles was favored by the higher temperatures, which were closer to the glass transition temperature of PVAc. This seems to indicate that the mobility of the polymer chains can be important for explanation of the obtained results. Apparently, the higher the mobility of the chains, the higher the amounts of BSA adsorbed on the PVAc microparticles. This can also explain why the adsorption process was more effective when the protein was close to its isoelectric point, as the absence of electrical charge can facilitate the interaction of the protein with the polymer surface. This result is also supported by previous results, which indicate that adsorption of BSA onto different supports is controlled by hydrophobic interactions and not by electrical charges ${ }^{[55-57]}$.

It is also important to observe that the total amount of BSA adsorbed onto the PVAc microparticles at $30^{\circ} \mathrm{C}$ and $\mathrm{pH}$ of 5.0 was equal to $0.65 \mathrm{mg} / \mathrm{g}$ of polymer, much smaller than values reported previously for BSA adsorption onto inorganic supports of very high specific area $(25 \mathrm{mg} / \mathrm{g}$ of support in the vicinities of the isoelectric point $)^{[57]}$. Assuming

Table 1. Experimental design for adsorption experiments.

\begin{tabular}{lcr}
\hline Code & Mass of PVAc $\mathbf{( g )}$ & pH \\
\hline PVAc-1 & 1 & 3.0 \\
PVAc-2 & 1 & 5.0 \\
PVAc-3 & 1 & 6.8 \\
PVAc-4 & 1 & 8.6 \\
PVAc-5 & 1 & 10.8 \\
PVAc-6 & 2 & 3.0 \\
PVAc-7 & 2 & 5.0 \\
PVAc-8 & 2 & 6.8 \\
PVAc-9 & 2 & 8.6 \\
PVAc-10 & 2 & 10.8 \\
Control-1 & 0 & 3.0 \\
Control-2 & 0 & 5.0 \\
Control-3 & 0 & 6.8 \\
Control-4 & 0 & 8.6 \\
Control-5 & 0 & 10.8 \\
\hline
\end{tabular}

that a single monolayer of BSA was formed over the particle surfaces, it is possible to conclude that the area occupied by each BSA molecule over the PVAc particles was equal to $5.2 \mathrm{~nm}^{2}$, which is much lower than areas reported previously for BSA over other supports (from 35 to $\left.44 \mathrm{~nm}^{2}\right)^{[38-40,56]}$. This clearly indicates that multiple BSA layers (as many as seven) can be formed over the PVAc particles or that BSA molecules can interact with PVAc chains and penetrate (through mixing) in the particle.

It is important to observe that the PVAc microparticles that were subjected to BSA adsorption experiments at $30^{\circ} \mathrm{C}$ and $\mathrm{pH}$ of 5.0 after 8 hours and containing $0.65 \mathrm{mg}$ of BSA per $g$ of polymer were filtrated, dried at room temperature in vacuum oven and resuspended in $10 \mathrm{ml}$ of aqueous medium at $30^{\circ} \mathrm{C}$ and $\mathrm{pH}$ of 5.0. As BSA could not be detected in the aqueous medium after $8 \mathrm{~h}$, desorption could be regarded as negligible at the analyzed conditions.

Figure 7 shows how the concentrations of lisozyme in the aqueous phase changed when the protein solution was kept in contact with the PVAc microparticles for 24 hours at $30^{\circ} \mathrm{C}$. As one can observe, significant changes of lisozyme concentrations could only be observed after 8 hours when the $\mathrm{pH}$ was equal to 8.6 , which is also close to the isoelectric point of lisozyme, as observed previously

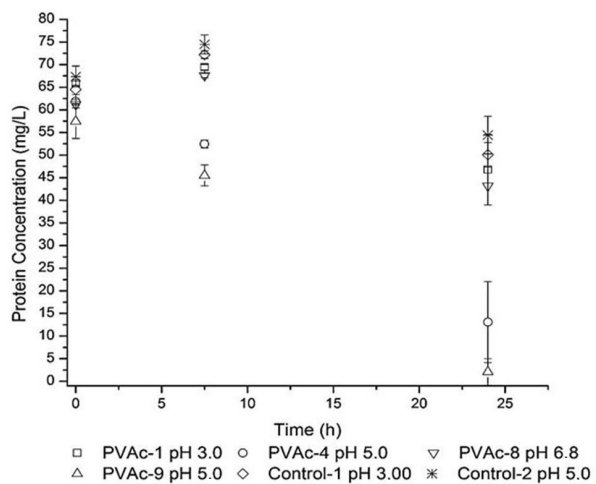

Figure 6. Concentration of BSA in the aqueous phase after 24 hours at $30^{\circ} \mathrm{C}$.

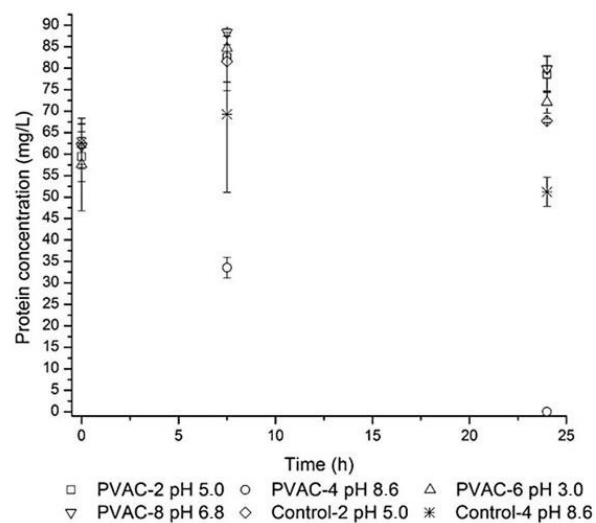

Figure 7. Concentration of lisozyme in the aqueous phase after 24 hours at $30^{\circ} \mathrm{C}$. 
for BSA. After 24 hours of experiment, significant changes of concentration could also be observed for the control experiments, indicating the protein denaturation in basic aqueous media, as described previously and confirmed independently through the enzymatic activity tests shown in Figure 8. As a consequence, lisozyme adsorption experiments performed in basic aqueous media must be shorter, if protein denaturation must be avoided. Once more, it is important to note that similar results were obtained when different amounts of PVAc ( 1 or $2 \mathrm{~g}$ ) were used, indicating that the obtained results were not controlled only by the small specific areas of the produced PVAc powder. As in the previous case, when similar experiments were performed at $10{ }^{\circ} \mathrm{C}$, no significant change of the lisozyme concentrations could be observed in the aqueous phase, indicating that temperature exerts a pronounced effect on the efficiency of lisozyme adsorption onto the PVAc microparticles, as also observed previously for BSA. Figure 9 shows the evolution of protein concentration and enzymatic lisozyme activity in the aqueous phase during the first ten hours of experiment, depicting that both dynamic trajectories are not proportional to each other and indicating that protein denaturation takes place at the $\mathrm{pH}$ value of 8.6 .

As done in the case of BSA, it is important to observe that the total amount of lisozyme adsorbed onto the PVAc microparticles at $30^{\circ} \mathrm{C}$ and $\mathrm{pH}$ of 8.6 after 8 hours was equal to $1.0 \mathrm{mg} / \mathrm{g}$ of polymer (or $25000 \mathrm{IU}$, in terms of activity), much smaller than values reported previously for lisozyme adsorption onto inorganic supports of very high specific area (385 to $450 \mathrm{mg} / \mathrm{g}$ of support in the vicinities of the isoelectric point) ${ }^{[52,58,59]}$. Assuming that a single monolayer of lisozyme was formed over the particle surfaces, it is possible to conclude that the area occupied by each lisozyme molecule over the PVAc particles was equal to $3.3 \mathrm{~nm}^{2}$, which is not compatible with the characteristic dimensions of the molecule and also indicates that multiple lisozyme layers can be formed over the PVAc particles or that lisozyme molecules can interact with PVAc chains and penetrate (through mixing) in the particle.

It is important to observe that the PVAc microparticles that were subjected to lisozyme adsorption experiments at $30{ }^{\circ} \mathrm{C}$ and $\mathrm{pH}$ of 8.6 after 8 hours and containing $1 \mathrm{mg}$ of lisozyme per $\mathrm{g}$ of polymer were filtrated, dried at room temperature in vacuum oven and used for characterization of residual enzymatic activity. Enzymatic activity tests were performed with $100 \mathrm{mg}$ of PVAc microparticles in $10 \mathrm{ml}$ of Micrococcus solution. Residual enzymatic activity was detected, but the consumption rates of the Micrococcus powder decreased at least two orders of magnitude, indicating the very slow release of the enzyme from the particle (Bradford tests could not detect significant release of protein in the aqueous phase, indicating that desorption was negligible at the analyzed experimental conditions) or denaturation of the enzyme.

Based on the results presented in the previous paragraphs for the model biomolecules BSA and lisozyme, the adsorption of proteins onto PVAc microparticles seems to be controlled by hydrophobic interactions, depending on the availability of interfacial surface (as usual), but also depending significantly on the mobility of the polymer chains. Besides, as adsorption efficiency was also higher in the vicinities of the isoelectric point of the protein, it seems that interaction can be maximized in the absence of charges, as also observed for other support/protein pairs ${ }^{[60]}$. Based on these results, it can be conjectured that as much as $1 \mathrm{mg}$ of protein can be loaded into $1 \mathrm{~g}$ of PVAc-based embolic agents through adsorption, if the adsorption process is performed

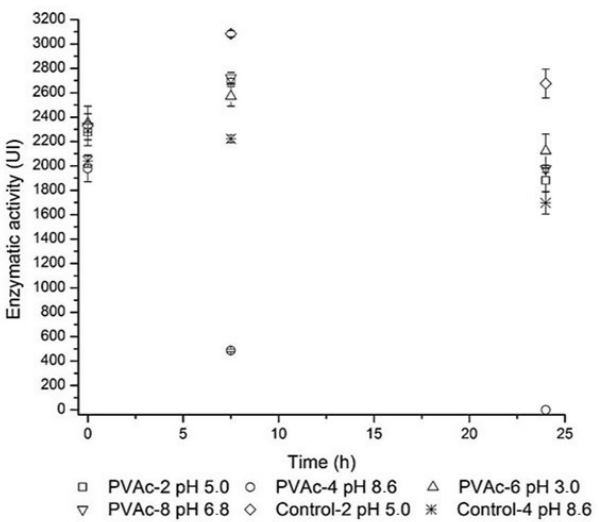

Figure 8. Enzymatic lisozyme activity in the aqueous phase after 24 hours at $30^{\circ} \mathrm{C}$.

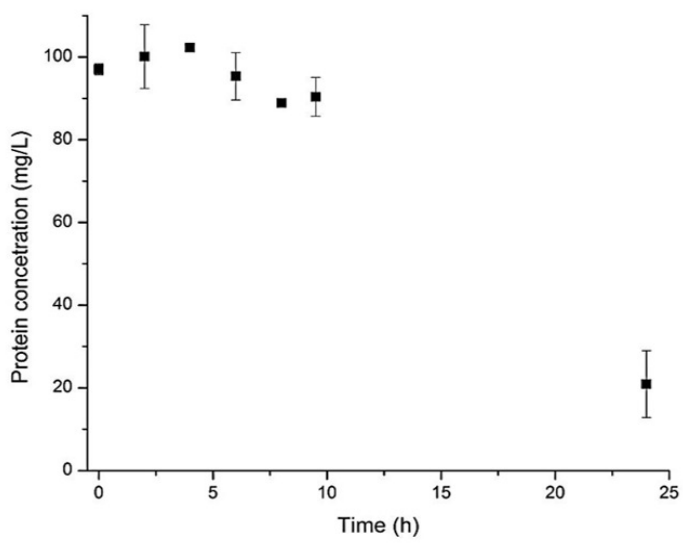

(a)

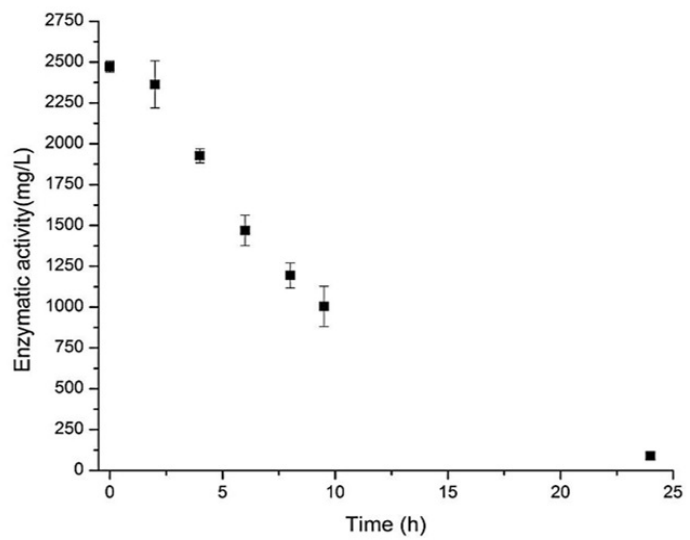

(b)

Figure 9. (a) Concentration of lisozyme and (b) enzymatic lisozyme activity in the aqueous phase at $30^{\circ} \mathrm{C}$ and $\mathrm{pH}$ of 8.6. 
in the vicinities of the isoelectric point of the protein of interest, which is comparable to the amounts required for some of the standard chemoterapic procedures.

\section{Conclusions}

The adsorption of bovine serum albuminum (BSA) and lysozyme (used as model biomolecules) on PVAc particles produced through suspension polymerization was studied in the present manuscript in a broad range of $\mathrm{pH}$ values. It was shown that significant amounts of BSA and lysozyme could be adsorbed onto PVAc particles in the vicinities of the isoelectric point of the biomolecules $(0.65 \mathrm{mg}$ of BSA and 1.0mg of lysozyme per g of PVAc), allowing for production of chemoembolizers through adsorption. Besides, it was shown that the adsorption of the analyzed proteins onto PVAc microparticles seemed to be controlled by hydrophobic interactions, depending significantly on the mobility of the polymer chains and on the net charges of the analyzed protein. Based on these results, it can be conjectured that as much as $1 \mathrm{mg}$ of protein can be loaded into $1 \mathrm{~g}$ of PVAc-based embolic agents through adsorption, if the adsorption process is performed in the vicinities of the isoelectric point of the protein of interest.

\section{Acknowledgements}

The authors thank CNPq (Conselho Nacional de Desenvolvimento Científico e Tecnológico, Brasil) and FAPERJ (Fundação Carlos Chagas Filho de Apoio à Pesquisa do Estado do Rio de Janeiro) for scholarships and financial support.

\section{References}

1. Cavallaro, G., Fresta, M., Giammona, G., Puglisi, G., \& Villari, A. (1994). Entrapment of $\beta$-lactams antibiotics in polyethylcyanoacrylate nanoparticles: Studies on the possible in vivo application of this colloidal delivery system. International Journal of Pharmaceutics, 111(1), 31-41. http:// dx.doi.org/10.1016/0378-5173(94)90399-9.

2. Brannon-Peppas, L. (1995). Recent advances on the use of biodegradable microparticles and nanoparticles in controlled drug delivery. International Journal of Pharmaceutics, 116(1), 1-9. http://dx.doi.org/10.1016/0378-5173(94)00324-X.

3. Fresta, M., Cavallaro, G., Giammona, G., Wehrli, E., \& Puglisi, G. (1996). Preparation and characterization of polyethyl-2cyanoacrylate nanocapsules containg antiepileptic drugs. Biomaterials, 17(8), 751-758. PMid:8730958. http://dx.doi. org/10.1016/0142-9612(96)81411-6.

4. Fontana, G., Pitarresi, G., Tomarchio, V., Carlisi, B., \& Biagio, P. L. S. (1998). Preparation, characterization and in vitro antimicrobial activity of ampicillin-loaded polyethylcyanoacrylate nanoparticles. Biomaterials, 19(11-12), 1009-1017. PMid:9692799. http://dx.doi.org/10.1016/S0142-9612(97)00246-9.

5. Uhrich, K. E., Cannizzaro, S. M., Langer, R. S., \& Shakesheff, K. M. (1999). Polymeric systems for controlled drug release. Chemical Reviews, 99(11), 3181-3198. PMid:11749514. http:// dx.doi.org/10.1021/cr940351u.

6. Pillai, O., \& Panchagnula, R. (2001). Polymers in drug delivery. Current Opinion in Chemical Biology, 5(4), 447451. PMid:11470609. http://dx.doi.org/10.1016/S13675931(00)00227-1.
7. Takahashi, T. (2002). Development and clinical application of drug delivery systems for cancer treatment. International Journal of Clinical Oncology, 7(4), 206-218. PMid:12202974. http://dx.doi.org/10.1007/s101470200032.

8. Iconomopoulou, S. M., Andreopoulou, A. K., Soto, A., Kallitsis, J. K., \& Voyiatzis, G. A. (2005). Incorporation of low molecular weight biocides into polystyrene-divinyl benzene beads. Journal of Controlled Release, 102(1), 223-233. PMid:15653147. http:// dx.doi.org/10.1016/j.jconrel.2004.10.006.

9. Choi, S. W., \& Kim, J. H. (2007). Design of surface-modified poly(D,L-lactide-co-glycolide) nanoparticles for targeted drug delivery to bone. Journal of Controlled Release, 122(1), 24-30. PMid:17628158. http://dx.doi.org/10.1016/j.jconrel.2007.06.003.

10. Voltan, R., Castaldello,A., Brocca-Cofano, E., Altavilla, G., Caputo, A., Laus, M., Sparnacci, K., Ensoli, B., Spaccasassi, S., Ballestri, M., \& Tondelli, L. (2007). Preparation and characterization of innovative protein-coated poly(methylmethacrylate) core-shell nanoparticles for vaccine purpose. Pharmaceutical Research, 24(10), 1870-1882. PMid:17476465. http://dx.doi.org/10.1007/ s11095-007-9310-8.

11. Liapi, E., Lee, K., Georgiades, C. C., Hong, K., \& Geschwind, J. H. (2008). Drug-eluting particles for interventional pharmacology. Techniques in Vascular and Interventional Radiology, 10(4), 261-269. PMid:18572139. http://dx.doi. org/10.1053/j.tvir.2008.03.003.

12. Ito, F., Fujimori, H., Honnami, H., Kawakami, H., Kanamura, K., \& Makino, K. (2008). Effect of polyethylene glycol on preparation of rifampicin-loaded PLGA microspheres with membrane emulsification technique. Colloids and Surfaces. B, Biointerfaces, 66(1), 65-70. PMid:18585903. http://dx.doi. org/10.1016/j.colsurfb.2008.05.011

13. Oliveira, M. A. M., Melo, P. A. Jr, Nele, M., \& Pinto, J. C. (2011). In-situ incorporation of amoxicillin in PVA/PVAcco-PMMA particles during suspension polymerization. Macromolecular Symposia, 299/300(1), 34-40. http://dx.doi. org/10.1002/masy.200900144

14. Oliveira, M.A.M., Melo, P.A. Jr., Nele, M., \& Pinto, J.C. (2012). Suspension copolymerization on vinyl acetate and methyl methacrylate in the presence of amoxicillin. Macromolecular Reaction Engineering, 6, 280-292. http://dx.doi.org/10.1002/ mren.201100083

15. Oliveira, M. A. M., Melo, P. A. Jr, Nele, M., \& Pinto, J. C. (2012). In situ incorporation of doxorubicin in copolymer particles during suspension polymerization. Macromolecular Symposia, 319(1), 23-33. http://dx.doi.org/10.1002/masy.201100249.

16. Kadir, S.(1982). Selected techniques in interventional radiology (pp. 104-141). London: W.B. Sunders. http://dx.doi. org/10.1148/145.3.606

17. Smith, S. J. (2000). Uterine fibroid embolization. American Family Physician, 61(12), 3601-3607, 3611-3612. PMid:10892632.

18. Kisilevzky, N., \& Martins, M. (2003). Embolização uterina para tratamento de mioma sintomático: experiência inicial e revisão da literatura. Radiologia Brasileira, 36(3), 129-140. http://dx.doi.org/10.1590/S0100-39842003000300003.

19. Mendes, W. D. S., Chagas, V. L. A., Pinto, J. C., Caldas, J. G., \& Espinosa, G. (2005). Embolização pré operatória de tumores renais com microparticulas esféricas de tecnologia nacional. (Spherus ${ }^{\circledR}$-First Line Brasil). Revista do Colégio Brasileiro de Cirurgiões, 32, 51-55. http://dx.doi.org/10.1590/ S0100-69912008000100012.

20. Owen, R. J. T. (2008). Embolization of musculoskeletal tumors. Radiologic Clinics of North America, 46(3), 535-543, vi. PMid:18707961. http://dx.doi.org/10.1016/j.rcl.2008.02.002.

21. Kato, T., Nemoto, R., Mori, H., \& Kumagai, I. (1980). Sustained-release properties of microencapsulated mitomycin $\mathrm{C}$ with ethylcellulose infused into the renal renal artery 
of the dog. Cancer, 46(1), 14-21. PMid:7388756. http:// dx.doi.org/10.1002/1097-0142(19800701)46:1<14::AIDCNCR2820460103>3.0.CO;2-N.

22. Kato, T., Nemoto, R., Mori, H., Takahashi, M., \& Harada, M. (1981). Arterial chemoembolization with mitomycin C microcapsules in the treatment of primary or secondary carcinoma of the kidney, liver, bone and intrapelvic organs. Cancer, 48(3), 674-680. PMid:6166362. http://dx.doi.org/10.1002/10970142(19810801)48:3<674::AID-CNCR2820480303>3.0.CO;2-E.

23. Wallace, S., Charnsangavej, C., Carrasco, C., \& Bechtel, W. (1984). Infusion-embolization. Cancer, 54(11, Suppl), 2751-2765. PMid:6093984. http://dx.doi.org/10.1002/10970142(19841201)54:2+<2751::AID-CNCR2820541423>3.0.CO;2-5.

24. Lewis, A. L., Gonzalez, M., Lloyd, A. W., Hall, B., Tang, Y., Willis, S. L., Leppard, S. W., Wolfenden, L. C., Palmer, R. R., \& Stratford, P. W. (2006). DC bead: in vitro characterization of a drug-delivery device for transarterial chemoembolization. Journal of Vascular and Interventional Radiology, 17(2 Pt 1), 335-342. PMid:16517780. http://dx.doi.org/10.1097/01. RVI.0000195323.46152.B3.

25. Pinto, J. C., Niemeyer, M., Espinosa, G., Silva, F. M., \& Melo, P. A. Jr. (2004). Patent PI04044952-7. Processo de síntese de poli(álcool vinílico) e/ou poli(acetato vinila) com morfologia esférica e estrutura casca-núcleo e seu uso na embolização vascular. Rio de Janeiro: INPI.

26. Laurent, A. (2007). Microspheres and nonspherical particles for embolization. Techniques in Vascular and Interventional Radiology, 10(4), 248-256. PMid:18572137. http://dx.doi. org/10.1053/j.tvir.2008.03.010.

27. Stampfl, S., Bellemann, N., Stampfl, U., Radeleff, B., LopezBenitez, R., Sommer, C.-M., Thierjung, H., Berger, I., \& Richter, G. M., (2008). Inflammation and recanalization of four different spherical embolization agents in the porcine kidney model. Journal of Vascular and Interventional Radiology, 19(4), 577-586. PMid:18375304. http://dx.doi.org/10.1016/j. jvir.2008.01.011.

28. Sandler, S. R., Karo, W., Bonesteel, J.-A., \& Pearce, E. M.(1998). Polymer synthesis and characterization. New York: Academic Press.

29. DeMerlis, C. C., \& Schoneker, D. R. (2003). Review of the oral toxicity of polyvinyl alcohol (PVA). Food and Chemical Toxicology, 41(3), 319-326. PMid:12504164. http://dx.doi. org/10.1016/S0278-6915(02)00258-2.

30. Santos, J. G. F. Jr, Peixoto, L. S., Nele, M., Melo, P. A., \& Pinto, J. C. (2006). Theorical and experimental investigation of the production of PMMA-based bone cement. Macromolecular Symposia, 243(1), 1-12.http://dx.doi.org/10.1002/masy.200651101.

31. Uchegbu, I. F., \& Schätzlein, A. G. (2006). Polymers in drug delivery. Memphis: LLC.

32. Peixoto, L. S., Silva, F. M., Niemeyer, M. A. L., Espinosa, G., Melo, P. A., Nele, M., \& Pinto, J. C. (2006). Synthesis of poly(vinyl alcohol) and/or poly(vinyl acetate) particles with spherical morphology and core-shell structure and its use in vascular embolization. Macromolecular Symposia, 243(1), 190-199. http://dx.doi.org/10.1002/masy.200651118.

33. Peixoto, L. S., Melo, P., Nele, M., \& Pinto, J. C. (2009). Expanded core/shell (poly(vinyl acetate)/poly(vinyl alcohol) particles for embolization. Macromolecular Materials and Engineering, 294(8), 463-471. http://dx.doi.org/10.1002/ mame. 200900028.

34. Peixoto, L. S., Cordeiro, F., Melo, P., Nele, M., \& Pinto, J. (2011). Synthesis of spherical core-shell PVAc-co-PMMA/PVA particles for use in vascular embolization. Macromolecular Symposia, 299-300(1), 132-138. http://dx.doi.org/10.1002/ masy.200900152.
35. Sulkowska, A. (2002). Interaction of drugs with bovine and human serum albumin. Journal of Molecular Structure, 614(1-3), 227-232. http://dx.doi.org/10.1016/S0022-2860(02)00256-9.

36. Sevilla, P., Rivas, J. M., García-Blanco, F., García-Ramos, J. V., \& Sánchez-Cortés, S. (2007). Identification of the antitumoral drug emodin binding sites in bovine serum albumin by spectroscopic methods. Biochimica et Biophysica Acta (BBA): Proteins and Proteomics, 1774(11), 1359-1369. http://dx.doi. org/10.1016/j.bbapap.2007.07.022.

37. Peng, M., Shi, S., \& Zhang, Y. (2012). Investigation of proton pump inhibitors binding with bovine serum albumin and their relationship to molecular. Journal of Luminescence, 132(8), 1921-1928. http://dx.doi.org/10.1016/j.jlumin.2012.03.011.

38. Goldberg, R. J. (1952). A theory of antibody antigen reactions 1: theory for reactions of multivalent antigen with bivalent and univalent antibody. Journal of the American Chemical Society, 74(22), 5715-5725. http://dx.doi.org/10.1021/ja01142a045.

39. Axelsson, I. (1978). Characterization of proteins and other macromolecules by agarose gel chromatography. Journal of Chromatography. A, 152(1), 21-32. http://dx.doi.org/10.1016/ S0021-9673(00)85330-3.

40. Hirayama, K., Akashi, S., Furuya, M., \& Fukuhara, K. (1990). Rapid confirmation and revision of the primary structure of bovine serum albumin by ESIMS and Frit-FAB LC/MS. Biochemical and Biophysical Research Communications, 173(2), 639-646. PMid:2260975. http://dx.doi.org/10.1016/ S0006-291X(05)80083-X.

41. Mastromatteo, M., Lecce, L., Vietro, N. D., Favia, P., \& Nobile, M. A. D. (2011). Plasma deposition processes from acrylic/methane on natural fibres to control the kinetic release of lysozyme from PVOH monolayer film. Journal of Food Engineering, 104(3), 373-379. http://dx.doi.org/10.1016/j. jfoodeng.2010.12.032.

42. Corradini, C., Alfieri, I., Cavazza, A., Lantano, C., Lorenzi, A., Zucchetto, N., \& Montenero, A. (2013). Antimicrobial films containing lysozyme for active packaging obtained by sol-gel technique. Journal of Food Engineering, 119(3), 580587. http://dx.doi.org/10.1016/j.jfoodeng.2013.05.046.

43. Arcan, I., \& Yemenicioglu, A. (2013). Development of fexible zein-wax composite and zein-fatty acid blend films for controlled release of lysozyme. Food Research International, 51(1), 208216. http://dx.doi.org/10.1016/j.foodres.2012.12.011.

44. Saravanan, R., Shanmugam, A., Ashok, P., Kumar, D. S., Anand, K., Suman, A., \& Devadoss, F. R. (2007). Studies on isolation and partial purification of lysozyme from egg white of the love bird (Agapornis species). African Journal of Biotechnology, 8, 107-109. http://dx.doi.org/10.5897/AJB.

45. Scaman, C., Nakai, S., \& Aminlari, M. (2005). Effect of pH, temperature and sodium bisulfite or cysteine on the level of maillard-based conjugation of lysozyme with dextran, galactomannan and mannan. Food Chemistry, 9, 368-380. http://dx.doi.org/10.1016/j.foodchem.2005.08.003.

46. Leysen, S., Van Herreweghe, J. M., Callewaert, L., Heirbaut, M., Buntinx, P., Michiels, C. W., \& Strelkov, S. V. (2011). Molecular basis of bacterial defense against host lysozymes: $\mathrm{x}$-ray structure of periplasmic lysozyme inhibitors Plil and PliC. Journal of Molecular Biology, 405(5), 1233-1245. PMid:21146533. http://dx.doi.org/10.1016/j.jmb.2010.12.007.

47. Xu, J., Wang, Z., Yu, L., Wang, J., \& Wang, S. (2013). A novel reverse osmosis membrane with regenerable anti-biofouling and chlorine resistant properties. Journal of Membrane Science, 435, 80-91. http://dx.doi.org/10.1016/j.memsci.2013.02.010.

48. Bradford, M. (1976). A rapid and sensitive method for the quantitation of microgram quantities of protein utilizing the principles of protein dye binding. Analytical Biochemistry, 
72(1-2), 248-254. PMid:942051. http://dx.doi.org/10.1016/00032697(76)90527-3.

49. Makki, F., \& Durance, T. D. (1996). Thermal inactivation of lysozyme as influenced by $\mathrm{pH}$, sucrose and sodium chloride and inactivation and preservative effect in beer. Food Research International, 29(7), 635-645. http://dx.doi.org/10.1016/S09639969(96)00074-9.

50. Chen, J.-P., \& Chen, Y.-C. (1997). Preparations of immobilized lysozyme with reversibly soluble polymer is hydrolysis of microbial cells. Bioresource Technology, 60(3), 231-237. http://dx.doi.org/10.1016/S0960-8524(97)00031-X.

51. Wang, S.-L., Chen, S.-H., Yen, Y.-H., \& Wang, C.-L. (2003). Reversible immobilization of lysozyme via coupling to reversibly soluble polymer. Enzyme and Microbial Technology, 33(5), 643-649. http://dx.doi.org/10.1016/S0141-0229(03)00186-8.

52. Chen, J.-F., Xiao, Q.-G., So, X., \& Zou, H.-K. (2008). Comparative study of solid silica nanoparticles and hollow silica nanoparticles for the immobilization of lysozyme. Chemical Engineering Journal, 137(1), 38-44. http://dx.doi. org/10.1016/j.cej.2007.09.012.

53. Ahmad, A., \& Salahuddin, A. (1996). Effect of organic solvents on lysozyme-antilysozyme precipitin reaction. Comparative Biochemistry and Physiology. Part C, Pharmacology, Toxicology \& Endocrinology, 114(2), 119-121. PMid:8760606. http:// dx.doi.org/10.1016/0742-8413(96)00020-5.

54. Castellan, G.(2004). Physical chemistry. 3rd ed. New Delhi: Narosa.

55. Zhang, D.-H., Zhang, Y.-F., Zhi, G.-Y., \& Xie, Y.-L. (2011). Effect of hydrophobic/hydrophilic characteristics of magnetic microspheres on the immobilization of BSA. Colloids and Surfaces. B, Biointerfaces, 82(2), 302-306. PMid:20888194. http://dx.doi.org/10.1016/j.colsurfb.2010.09.001.

56. Wangkam, T., Yodmongkol, S., Disrattakit, J., Sutapun, B., Amarit, R., Somboonkaew, A., \& Srikhirin, T. (2012). Adsorption of bovine serum albumin (BSA) on polystyrene (PS) and its acid copolymer. Current Applied Physics, 12(1), 44-52. http://dx.doi.org/10.1016/j.cap.2011.04.039.

57. Swain, S. K., \& Sarkar, D. (2013). Study of BSA protein adsorption/release on hydroxyapatite nanoparticles. Applied Surface Science, 286, 99-103. http://dx.doi.org/10.1016/j. apsusc.2013.09.027.

58. Lu, Z., Zhang, J., Ma, Y., Song, S., \& Gu, W. (2012). Biomimetic mineralization of calcium carbonate/carboxymethylcellulose microspheres for lysozyme immobilization. Materials Science and Engineering C, 32(7), 1982-1987. http://dx.doi.org/10.1016/j. msec.2012.05.027.

59. Lu, A. X., Liao, X. P., Zhou, R. Q., \& Shi, B. (2007). Preparation of Fe(III)-immobilized collagen fiber for lysozyme adsorption. Colloids and Surfaces, 301(1-3), 85-93. http://dx.doi.org/10.1016/j. colsurfa.2006.12.027.

60. Kim, J.-H., \& Yoon, J.-Y. (2002). Protein adsorption on polymer. In A. T. Hubbard (Ed.), Encyclopedia of surface and colloid science. New York: Marcel Dekker.

Received: Aug. 21, 2015

Revised: Feb. 01, 2016

Accepted: June 26, 2016 